\title{
Bi-level programming model and genetic simulated annealing algorithm for inland collection and distribution system optimization under uncertain demand
}

\author{
Cao, Q.K. ${ }^{a}$, Qin, M.N. ${ }^{a}$, Ren, X.Y., \\ ${ }^{a}$ School of Management Engineering and Business, Hebei University of Engineering, Handan, Hebei, P.R. China
}

\begin{abstract}
A B S T R A C T
With the continuous improvement of users' expectation of transportation quality and the continuous improvement of the transportation system in China, the inland collection system plays an increasingly important role in port development. Based on the demand change, this paper measures the disturbance of the demand change to the inland collection and distribution system from ports and customers, it establishes bi-level programming model for transportation route and transportation mode selection. The upper layer establishes the stochastic opportunity constrained programming model with the minimum cost of collection and distribution, the lower layer builds an optimization model with the goal of maximum customer satisfaction. The genetic simulated annealing algorithm is used to solve the bi-level programming model combined with specific examples and compared with genetic algorithm. The result shows that genetic simulated annealing algorithm can not only obtain the optimal solution, but also improve the speed of global convergence. The genetic simulated annealing algorithm is an effective algorithm to solve the bi-level programming model with multiple targets.
\end{abstract}

\author{
ARTICLE INFO \\ Keywords: \\ Inland collection and distribution \\ system; \\ Uncertain demand; \\ Optimization; \\ Bi-level programming model; \\ Genetic simulated annealing algo- \\ rithm

\begin{abstract}
*Corresponding author: boyrenxy@126.com
\end{abstract} \\ (Ren, X.Y.) \\ Article history: \\ Received 13 July 2017 \\ Revised 2 March 2018 \\ Accepted 28 May 2018
}

\section{References}

[1] Zhang, Y.-Q. (2011). Current status and optimal analysis of consolidation and distribution system of China's ports, Logistics Engineering and Management, Vol. 33, Vol. 6, 9-10, doi:10.3969/j.issn.1674-4993.2011.06.002.

[2] Zhou, X., Chen, X., Shao, L. (2017). Study on the optimization of collection and distribution system of freight hub ports: Illustrated by the case of Shanghai international shipping center, China, Transportation Research Procedia, Vol. 25, 1126-1136, doi: 10.1016/j.trpro.2017.05.125.

[3] Tang, Y., Tan, S.-Q. (2009). Current status and analysis of port container collecting and distributing system, Logistics Engineering and Management, Vol. 3, 34-35, doi: 10.3969/i.issn.1674-4993.2009.03.014.

[4] Iannone, F. (2012). The private and social cost efficiency of port hinterland container distribution through a regional logistics system, Transportation Research Part A: Policy \& Practice, Vol. 46, No. 9, 1424-1448, doi: 10.1016/i.tra.2012.05.019

[5] Sun, B. (2016). Study on countermeasures of applying inter-model transport BL for international railway through transportation of China-Europe block train, Railway Transport and Economy, Vol. 38, No. 4, 68-72, doi: 10.16668/i.cnki.issn.1003-1421.2016.04.15.

[6] Du, F., Evans, G.W. (2008). A bi-objective reverse logistics network analysis for post-sale service, Computers \& Operations Research, Vol. 35, No. 8, 2617-2634, doi: 10.1016/j.cor.2006.12.020.

[7] Chang, T.-S. (2008). Best routes selection in international intermodal networks, Computers \& Operations Research, Vol. 35, No. 9, 2877-2891, doi: 10.1016/i.cor.2006.12.025.

[8] Arnone, M., Mancini, S., Rosa, A. (2014). Formulating a mathematical model for container assignment optimization on an intermodal network, Procedia - Social and Behavioral Sciences, Vol. 111, 1063-1072, doi: 10.1016/j.sbspro.2014.01.141. 
[9] Chen, X., Sun, C. (2015). Study on cargo flow allocation in inter-modal container transportation based on supernetwork, Logistics Technology, Vol. 5, 204-208, doi: 10.3969/j.issn.1005-152X.2015.05.062.

[10] Luo, M., Grigalunas, T.A. (2003). A spatial-economic multimodal transportation simulation model for US coastal container ports, Maritime Economics \& Logistics, Vol. 5, No. 2, 158-178, doi: 10.1057/palgrave.mel.9100067.

[11] Zehendner, E., Feillet, D. (2014). Benefits of a truck appointment system on the service quality of inland transport modes at a multimodal container terminal, European Journal of Operational Research, Vol. 235, No. 2, 461-469, doi: 10.1016/i.ejor.2013.07.005.

[12] Dong, J.-S. (2007). Optimal model of collection and distribution system for the ports, Journal of University of Shanghai for Science and Technology, Vol. 5, 453-456, doi: 10.3969/i.issn.1007-6735.2007.05.010.

[13] Liu, X.-C., He, S.-W., Sun, Y., Li, H.-D., Jing, Y. (2016). Comprehensive transportation mixed network design and freight flow allocation based on cloud harmony search algorithm, Journal of Jilin University (Engineering and Technology Edition), Vol. 46, No. 1, 108-113, doi: 10.13229/i.cnki.jdxbgxb201601016.

[14] Nossack, J., Pesch, E. (2013). A truck scheduling problem arising in intermodal container transportation, European Journal of Operational Research, Vol. 230, No. 3, 666-680, doi: 10.1016/j.ejor.2013.04.042.

[15] Feng, Z., Liu, J., Li, J., Cao, Y.-F. (2010). Research on the algorithm for shortest path problem in complicated network, Techniques of Automation and Applications, Vol. 3, No. 43, 32-35, doi: 10.3969/j.issn.1003-7241.2010. 03.009.

[16] Wang, W.F., Yun, W.Y. (2013). Scheduling for inland container truck and train transportation, International Journal of Production Economics, Vol. 143, No. 2, 349-356, doi: 10.1016/i.ijpe.2011.10.016.

[17] Sterzik, S., Kopfer, H. (2013). A tabu search heuristic for the inland container transportation problem, Computers \& Operations Research, Vol. 40, No. 4, 953-962, doi: 10.1016/i.cor.2012.11.015.

[18] Pishvaee, M.S., Farahani, R.Z., Dullaert W. (2010). A memetic algorithm for bi-objective integrated forward/reverse logistics network design, Computers \& Operations Research, Vol. 37, No. 6, 1100-1112, doi: 10.1016/i.cor.2009.09.018.

[19] Huang, C., Zhang, Q., Xu, Y. (2013). Transportation network decision model based on the extended hub-andspoke, Journal of Wuhan University of Technology (Transportation Science \& Engineering), Vol. 5, 974-978, doi: 10.3963/i.issn.2095-3844.2013.05.018.

[20] $\mathrm{Wu}, \mathrm{Z}$. (2014). Optimization of distribution route selection based on particle swarm algorithm, International Journal of Simulation Modelling, Vol. 13, No. 2, 230-242, doi: 10.2507/IJSIMM13(2)CO9.

[21] Zhao, M.X., Gao, Z.Y. (2005). A global convergent method for linear bilevel programs based on penalty function, Operations Research and Management Science, Vol. 14, No. 4, 25-28.

[22] Wan, Z., Ji, C., Wang, X. (1999). A dual approaching algorithm for solving a class of bilevel linear programming problem, Systems Engineering - Theory \& Practice, Vol. 5, 125-128, doi: 10.3321/j.issn:1000-6788.1999.05.024.

[23] Sun, H., Gao, Z. (2004). An optimization model for two-echelon distribution network design in supply chain based on bi-level programming, Journal of Industrial Engineering and Engineering Management, Vol. 1, 68-71, doi: 10.3969/j.issn.1004-6062.2004.01.017. 